\title{
Endoscopic endonasal transpterygoid approach for reduction of a lateral recess encephalocele with postoperative cerebrospinal fluid leak
}

\author{
Adham M Khalafallah, ${ }^{1}$ Omar G Ahmed, ${ }^{2}$ Nicholas R Rowan, ${ }^{2}$ Debraj Mukherjee (i) ${ }^{1}$
}

${ }^{1}$ Neurosurgery, Johns Hopkins School of Medicine, Baltimore, Maryland, USA

${ }^{2}$ Otolaryngology-Head and Neck Surgery, Johns Hopkins School of Medicine, Baltimore, Maryland, USA

\section{Correspondence to} Dr Debraj Mukherjee; dmukher1@jhmi.edu

Accepted 16 July 2020

\section{DESCRIPTION}

The authors present an endoscopic endonasal transpterygoid approach for reduction of a lateral recess encephalocele with post-operative cerebrospinal fluid leak. A 43-year-old man presented with right-sided clear rhinorrhea for 2 years. He had no other sinus complaints. On examination, he had a body mass index of 28 and right-sided clear rhinorrhea while leaning his head forward. ${ }^{12}$ This fluid was collected and found to be positive for beta- 2 transferrin. The patient was assessed for idiopathic

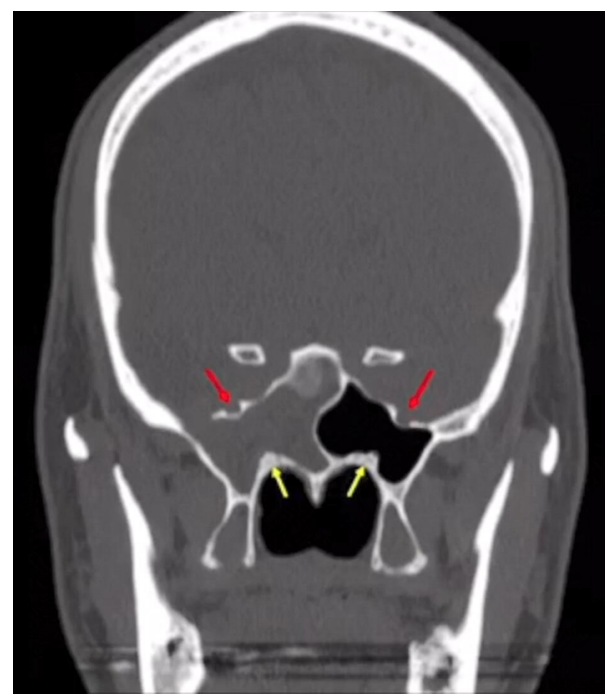

Figure 1 From minute (0:38-0:50)—a coronal CT study in the bone window demonstrated a right lateral sphenoid sinus skull base defect between foramen rotundum indicated by the red arrow and the vidian canal indicated by the yellow arrow.

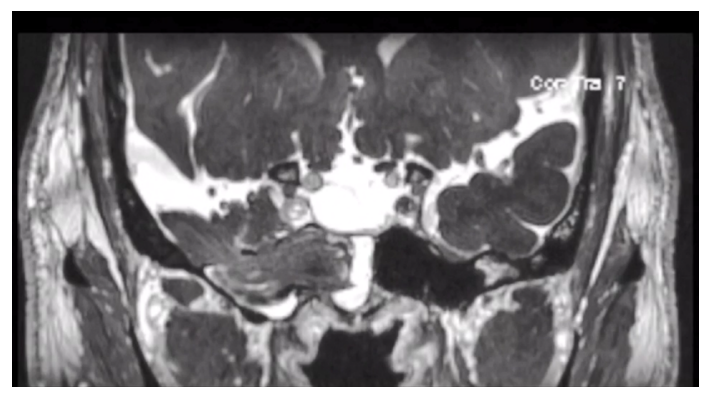

Figure 2 From minute (0:51-0:59) — a T2 weighted coronal MRI demonstrated a large sphenoid sinus encephalocele herniating through a right lateral recess skull base defect. intracranial hypertension (IIH), and he had no evidence of IIH. The patient had no signs of papilloedema on assessment by the neuro-ophthalmology team before or after surgery. The patient had no history of meningitis, trauma, obstructive sleep apnoea or any recent weight changes. CT and MRI of the skull base were obtained (figures 1 and 2). A bony defect was found, the size of the defect was $9.5 \mathrm{~mm}$ in maximal diameter. The steps of the transpterygoid technique and reconstruction are explained in detail through video $1 .^{3-14}$

Postoperatively, the patient refused to adhere to the postoperative bed rest protocol. Sixteen hours after surgery, the patient began to have clear rhinorrhea. The index of suspicion for a cerebrospinal fluid leak was high, and the decision was made to take the patient back to the operating room for re-exploration on postoperative day 2. From this case, we can learn from several technical errors through demonstrating the pitfalls and nuances of the technique. First, full reduction of the encephalocele helps to identify margins of the skull base defect. It is also essential to ensure appropriate preparation of the nasoseptal flap recipient site by skeletonising the skull base, including removal of residual bony edges and removal of sphenoid sinus mucosa. Lastly, we recommend immediate postoperative bed rest and ongoing acetazolamide for our patients following surgical repair of spontaneous cerebrospinal fluid leaks of the anterior skull base.

Twitter Adham M Khalafallah @KhalafallahAM and Debraj Mukherjee @NeuroOncSurgery

Contributors AMK: Conception and design of the case, video creation and editing, writing — original draft, writing — review and editing, final approval of the version published. OGA: Conception and design of the case, video editing, writing — review and

\section{Learning points}

- Full reduction of the encephalocele helps to identify margins of the skull base defect.

- Ensure appropriate preparation of the nasoseptal flap recipient site by skeletonising the skull base, including removal of residual bony edges and removal of sphenoid sinus mucosa.

- Immediate postoperative bedrest and ongoing acetazolamide for patients following surgical repair of spontaneous cerebrospinal fluid leaks of the anterior skull base. 


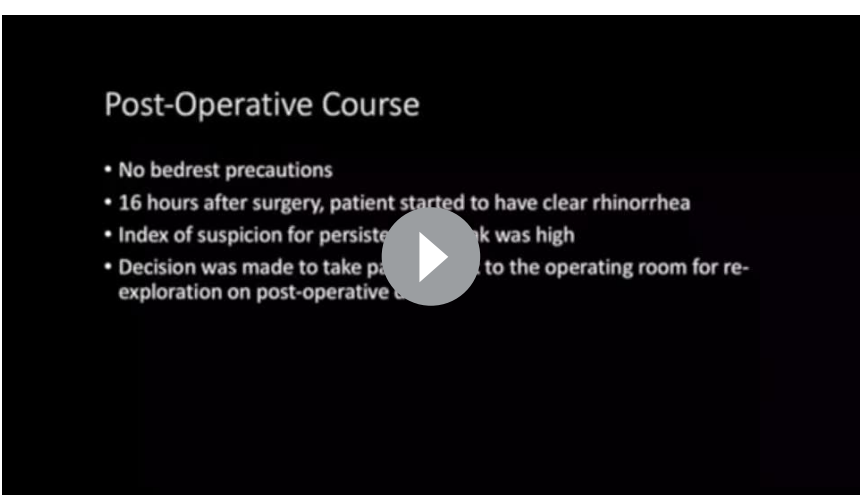

Video 1 Endoscopic endonasal transpterygoid approach for reduction of a lateral recess encephalocele.

editing, final approval of the version published. NRR: Conception and design of the case, writing - review and editing, final approval of the version published. DM: Conception and design of the case, video editing, writing — review and editing, final approval of the version published.

Funding The authors have not declared a specific grant for this research from any funding agency in the public, commercial or not-for-profit sectors.

Competing interests None declared.

Patient consent for publication Not required.

Provenance and peer review Not commissioned; externally peer reviewed.

ORCID iD

Debraj Mukherjee http://orcid.org/0000-0002-5403-8237

\section{REFERENCES}

1 Fraser S, Gardner PA, Koutourousiou M, et al. Risk factors associated with postoperative cerebrospinal fluid leak after endoscopic endonasal skull base surgery. $J$ Neurosurg 2016:128

2 Choi J-E, Noh Y-S, Lee KE, et al. Morbidities associated with the endoscopic transnasal transpterygoid approach: focusing on postoperative sequelae. World Neurosurg 2020;137:e43-51.

3 Alexander NS, Chaaban MR, Riley KO, et al. Treatment strategies for lateral sphenoid sinus recess cerebrospinal fluid leaks. Arch Otolaryngol Head Neck Surg 2012;138:471-8

4 Patel KS, Komotar RJ, Szentirmai O, et al. Case-specific protocol to reduce cerebrospinal fluid leakage after endonasal endoscopic surgery. J Neurosurg 2013;119:661-8.

5 Castelnuovo P, Dallan I, Pistochini A, et al. Endonasal endoscopic repair of Sternberg's canal cerebrospinal fluid leaks. Laryngoscope 2007;117:345-9.

6 El-Banhawy OA, Halaka AN, El-Dien AE-HS, et al. Sellar floor reconstruction with nasal turbinate tissue after endoscopic endonasal transsphenoidal surgery for pituitary adenomas. Minim Invasive Neurosurg 2003;46:289-92.

7 Ulu MO, Aydin S, Kayhan A, et al. Surgical management of sphenoid sinus lateral recess cerebrospinal fluid leaks: a single neurosurgical center analysis of endoscopic endonasal minimal transpterygoid approach. World Neurosurg 2018;118:e473-82.

8 Cavallo LM, Messina A, Esposito F, et al. Skull base reconstruction in the extended endoscopic transsphenoidal approach for suprasellar lesions. J Neurosurg 2007;107:713-20.

9 Hadad G, Bassagasteguy L, Carrau RL, et al. A novel reconstructive technique after endoscopic expanded endonasal approaches: vascular pedicle nasoseptal flap. Laryngoscope 2006;116:1882-6.

10 Kassam AB, Thomas A, Carrau RL, et al. Endoscopic reconstruction of the cranial base using a pedicled nasoseptal flap. Neurosurgery 2008;63.

11 Pinheiro-Neto CD, Fernandez-Miranda JC, Prevedello DM, et al. Transposition of the pterygopalatine fossa during endoscopic endonasal transpterygoid approaches. J Neurol Surg B Skull Base 2013;74:266-70.

12 Tormenti MJ, Paluzzi A, Pinheiro-Nieto C, et al. Endoscopic endonasal repair of spontaneous CSF fistulae. J Neurosurg 2012;32:E6.

13 Zanation AM, Carrau RL, Snyderman CH, et al. Nasoseptal flap takedown and reuse in revision endoscopic skull base reconstruction. Laryngoscope 2011;121:42-6.

14 Snyderman $\mathrm{CH}$, Wang EW, Zenonos GA, et al. Reconstruction after endoscopic surgery for skull base malignancies. J Neurooncol 2020. doi:10.1007/s11060-020-03465-0. [Epub ahead of print: 27 Mar 2020].

Copyright 2020 BMJ Publishing Group. All rights reserved. For permission to reuse any of this content visit

https://www.bmj.com/company/products-services/rights-and-licensing/permissions/

BMJ Case Report Fellows may re-use this article for personal use and teaching without any further permission.

Become a Fellow of BMJ Case Reports today and you can:

- Submit as many cases as you like

- Enjoy fast sympathetic peer review and rapid publication of accepted articles

- Access all the published articles

Re-use any of the published material for personal use and teaching without further permission

Customer Service

If you have any further queries about your subscription, please contact our customer services team on +44 (0) 2071111105 or via email at support@bmj.com.

Visit casereports.bmj.com for more articles like this and to become a Fellow 